\title{
) Hydrocortisone acetate-loaded PCL nanoparticles as an innovative dermatological therapy for atopic dermatitis
}

\author{
Nanopartículas de PCL com acetato de hidrocortisona como uma terapia dermatológica \\ inovadora para a dermatite atópica
}

Catarina Pinto Reis, Ana Rita Jerónimo, Pedro Pinto, Catarina Oliveira Silva \& Sara Candeias

CBIOS - Universidade Lusófona's Research Center for Health Science and Technologies (UDE), Campo Grande 376, 1749-024, Lisboa, Portugal

Email: catarina.reis@ulusofona.pt

\begin{abstract}
Atopic dermatitis is a chronic cutaneous pathology, which requires intensive skin care and pharmacological therapy; current available treatments still need urgent improvements, especially for long-term use and specific groups (e.g. children). Nanotechnology has contributed with innovative drug delivery systems and can offer effective targeted therapies. Study purposes were to prepare and to characterize hydrocortisone acetate-loaded polycaprolactone nanoparticles in terms of their physicochemical properties, encapsulation efficiency, in vitro drug release and in vivo safety studies of the used excipients in human subjects. Resultant nanoparticles had a mean size of $258.424 .5 \mathrm{~nm}$ and polydispersity index of 0.084 . Zeta potential was $-4.390 .62 \mathrm{mV}$ and the efficiency encapsulation was 36.32 $0.03 \%$. In addition, in vitro release studies demonstrated a prolonged release of drug from the nanoparticles over time. Moreover, preliminary safety studies indicated that the formulation was well tolerated.

This study demonstrates that acetate hydrocortisone-loaded nanoparticles are stable systems that can lead to a prolonged release of the drug with promising results in terms of safety when applied to the human skin.
\end{abstract}

Keywords: Atopic dermatitis; poly(-caprolactone) nanoparticles; hydrocortisone acetate; safety studies.

\begin{abstract}
Resumo
A dermatite atópica é uma patologia cutânea crónica que requer cuidados intensivos da pele e tratamento farmacológico; contudo, os tratamentos disponíveis necessitam urgentemente de ser melhorados, especialmente quando utilizados por períodos longos ou em grupos específicos (ex: crianças). A nanotecnologia tem contribuído com sistemas de veiculação inovadores e pode oferecer terapias efectivas e direcionadas. Os objectivos deste estudo centraram-se na preparação caracterização das nanopartículas de policaprolactona carregadas com acetato de hidrocortisona em termos das propriedades físico-químicas, eficiência de encapsulação, ensaios de libertação in vitro e ensaios de segurança dos excipientes utilizados em voluntários humanos. As nanopartículas produzidas apresentaram um tamanho médio de $258,424,5 \mathrm{~nm}$ e um índice de polidispersão de 0,084 . O potencial zeta foi -4,39 $0,62 \mathrm{mV}$ e a eficiência de encapsulação foi $36,320,03 \%$. A libertação in vitro do fármaco foi controlada ao longo do tempo. Além disso, os testes de segurança indicaram que os excipientes foram bem tolerados. Este estudo demonstra que as nanopartículas de policaprolactona são sistemas estáveis para veiculação de acetato de hidrocortisona que poderão conduzir a uma libertação prolongada do fármaco, com resultados promissores ao nível da sua segurança quando aplicados na pele humana.
\end{abstract}

Palavras-chave: Dermatite atópica; nanopartículas poli(-caprolactona); acetato de hidrocortisona; ensaios de segurança. 


\section{Introduction}

Atopic dermatitis is a complex chronic dermatological disease, characterized by a multifactorial etiology (e.g. genetics factors, environmental factors and impaired immune responses), which involves inflammatory and pruriginous responses ${ }^{-[12]}$. This pathology has a considerable impact on the quality of life since it requires intensive skin care and continuous pharmacological measures ${ }^{[1,2,7,8,10,11,1315]}$.

Currently, there is a broad spectrum of therapeutic approaches including topical corticosteroids, such as the hydrocortisone acetate (HCA), which has antiinflammatory, antipruritic and vasoconstrictive properties $[1,4,8,9,12,13]$. The mechanism of action of this topical therapeutic class is based on the drug's ability to cross the stratum corneum. The percutaneous absorption is related to numerous factors such as the integrity of epidermal tissue, occlusive state and formulation vehicle [16]. Although topical corticosteroids are still important therapeutic agents especially in intermittent immunological hyperreactivity periods, they have demonstrated significant side effects that can limit patient compliance $[1,4,8,9,12,13,17]$.

Nanotechnology has been applied in the context of medicine and pharmaceutical sciences for diagnostic purposes, treatment and prevention of a diversity of pathologies [18,19]. Indeed, several groups demonstrated that biodegradable polymeric nanoparticles (NPs) are particularly relevant drug delivery systems due to their great potential to deliver the pharmacologically active compound to a specific therapeutic target (increased specificity), to protect pharmacological agents from degradation (increased stability), to control their release rate and show a reduced toxicological profile (safety and increased biocompatibility) ${ }^{-[18,2022]}$. Moreover, NPs are distinguished drug delivery systems due to their small size (increased surface-area-to-volume ratio) as well as strong adhesion to inflamed tissues [18,20,21,23].

Poly(-caprolactone) (PCL) is an interesting biodegradable and biocompatible polymer, which presents a significantly slower degradation than other available biodegradable polymers (e.g. PLGA, PLA). This fact is generally attributed to the resistance of chemical hydrolysis and to the high permeability of many drugs which leads to a significant retention inside the NPs core ${ }^{[2426]}$. Due to these properties, PCL is a good candidate for developing long-term use and safe drug delivery systems. We expect that encapsulation of HCA into PCL NPs can enable a prolonged drug release, associated with targeting action to inflammatory skin cells (e.g. epidermal keratinocytes). If this hypothesis is confirmed, HCA-loaded NPs could reduce the adverse side effects associated with the

\section{Introdução}

A dermatite atópica é uma doença dermatológica crónica complexa - caracterizada por uma etiologia multifactorial (ex: factores genéticos, factores ambientais e respostas imunitária exacerbadas) - que envolve uma resposta inflamatória e pruriginosa $[1,2,5,6,8,10,12]$. Esta patologia tem um impacto considerável na qualidade de vida, uma vez que requer cuidados intensivos da pele e medidas farmacológicas contínuas $[1,2,7,8,10,11,1315]$

Actualmente existe um vasto espectro de abordagens terapêuticas, incluindo os corticosteróides tópicos tais como o acetato de hidrocortisona (AHC) que apresenta propriedades anti-inflamatórias, antipruríticas e vasoconstrictoras ${ }^{[1,4,8,9,12,13]}$. O mecanismo de acção desta classe terapêutica a nível tópico é baseado na capacidade do fármaco permear o estrato córneo. A absorção percutânea está relacionada com uma série de factores como a integridade do tecido epidérmico, o estado oclusivo e o veículo da formulação ${ }^{[16]}$. Apesar dos corticosteróides tópicos serem agentes terapêuticos importantes, especialmente nos períodos de hiper-reactividade imunológica intermitente, têm demonstrado reacções adversas significativas que podem comprometer a adesão terapêutica ${ }^{[1,4,8,9,12,13,17]}$.

A nanotecnologia tem sido aplicada no contexto da medicina e das ciências farmacêuticas para fins de diagnóstico, tratamento e prevenção de uma diversidade de patologias ${ }^{[18,19]}$. De facto, vários grupos de investigação têm demonstrado que as nanopartículas poliméricas (NPs) biodegradáveis são sistemas de veiculação de fármacos particularmente relevantes devido ao seu grande potencial para direccionar e distribuir o composto farmacologicamente activo para o alvo terapêutico específico (maior especificidade), proteger os agentes farmacológicos da degradação (maior estabilidade), controlar a sua libertação e apresentam um perfil toxicológico reduzido (maior segurança e biocompatibilidade) ${ }^{-[18,2022]}$. Além disso, as NPs constituem um sistema terapêutico distinto devido ao seu pequeno tamanho (razão área de superfície-volume aumentada), assim como uma forte adesão aos tecidos inflamados ${ }^{[18,20,21,23]}$.

A poli(-caprolactona) (PCL) é um polímero biodegradável e biocompatível interessante pois apresenta uma degradação mais lenta do que outros polímeros biodegradáveis disponíveis (ex: PLGA, PLA). Este facto pode ser atribuído a uma possível resistência à hidrólise química e à elevada permeabilidade a muitos fármacos, o que promove a retenção destes últimos no núcleo das NPs ${ }^{[2426]}$. Devido a estas propriedades, este polímero é considerado um bom candidato para o desenvolvimento de sistemas de veiculação de fármacos a longo prazo e seguros. 
corticosteroid therapy, increase the efficiency of the treatment and, eventually, reduce the number of applications during the treatment, which may increase the patients' compliance ${ }^{[27]}$.

The objectives of this study are the preparation and characterization of HCA-loaded PCL NPs and evaluation of their physicochemical properties, encapsulation efficiency (EE), drug release and safety of NPs formulation.

\section{Material and methods}

\section{Chemical compounds}

Hydrocortisone 21-acetate (MW: $404.50 \mathrm{gmol}^{-1}$ ) and poly(-caprolactone) (MW: $14000 \mathrm{~g} \mathrm{~mol}^{-1}$ ) were obtained from Sigma-Aldrich (China and Japan, respectively). Polysorbate 80 (TWEEN 80) was supplied by Fluka Analytical/Sigma-Aldrich (Switzerland). Dexamethasone (DM) (MW: 392.47 $\mathrm{gmol}^{-1)}$ was supplied by AppliChem (Germany) and cortisone acetate (CA) (MW: $402.48 \mathrm{gmol}^{-1}$ ) was obtained from The Laboratory Labor Dr. EhrenstorferSchafers (Germany). Hydrocortisone (MW: 362.46 $\mathrm{gmol}^{-1}$ ) was provided from Sanofi Aventis (Portugal). All other chemicals were of reagent analytical grade.

\section{NPs production and extraction methods HCA-loaded PCL NPs production}

Empty and HCA-loaded PCL NPs were prepared by modified solvent displacement method previously referenced in the literature ${ }^{[27]}$. In brief, $10 \mathrm{mg}$ of HCA were suspended in $20 \mathrm{~mL}$ of methanol and, simultaneously, $250 \mathrm{mg}$ of PCL were dissolved in 50 $\mathrm{mL}$ of acetone for approximately $30 \mathrm{~min}$. These preparations were added to $100 \mathrm{~mL}$ of external aqueous phase that include $2 \%(\mathrm{v} / \mathrm{v})$ of TWEEN 80 under stirring rate of $100 \mathrm{rpm}$ (IKA Labortechnik, RW 20n, Germany). Particles were instantaneously formed. Empty NPs were also prepared.

\section{NPs recovery method}

Acetone was removed in a rotary evaporator at $40 \mathrm{C}$ and the NPs obtained were then recovered from the aqueous phase by centrifugation (High Speed Table Top Centrifuge Z 36 HK, Hermle Labortechnik, Germany) at $37130 \mathrm{~g},-4 \mathrm{C}$ for $40 \mathrm{~min}$.
Espera-se que encapsulação do AHC em NPs de PCL conduza a uma libertação de fármaco controlada e prolongada no tempo, associada a uma acção direcionada para células inflamatórias da pele (ex: queratinócitos epidermais). Se a nossa hipótese se confirmar, as NPs com AHC poderão reduzir os efeitos secundários relacionados com a terapêutica com corticosteróides, aumentar a eficácia do tratamento e, em última instância, reduzir o número de aplicações durante o tratamento, aumentando a adesão do doente à terapêutica ${ }^{[27]}$.

Os objectivos deste estudo são a preparação e caracterização das NPs de PCL carregadas com AHC e avaliação das suas propriedades físico-químicas, eficiência de encapsulação (EE), ensaios de libertação e segurança das Nps.

\section{Materiais e métodos}

\section{Compostos químicos}

21-Acetato de hidrocortisona (MM:404,50 $\mathrm{gmol}^{-1}$ ) e poli(-caprolactona) (MM:14000 $\mathrm{g} \mathrm{mol}^{-1}$ ) foram obtidos à Sigma-Aldrich (China e Japão, respectivamente). Polissorbato 80 (TWEEN 80) foi fornecido pela Fluka Analytical/Sigma-Aldrich (Suíça). Dexametasona (DM) (MM:392,47 $\mathrm{g} \mathrm{mol}^{-1}$ ) foi fornecida pela AppliChem (Alemanha) e o acetato de cortisona (AC) (MM:402,48 $\mathrm{gmol}^{-1}$ ) foi obtido do Laboratory Labor Dr. Ehrenstorfer-Schafers (Alemanha). A hidrocortisona (HC) (MM:362,46 $\mathrm{gmol}^{-1}$ ) foi obtida da Sanofi Aventis (Portugal). Os restantes reagentes foram de grau analítico.

\section{Métodos de produção e extracção das NPs Produção das NPs de PCL com AHC}

As NPs de PCL vazias e as carregadas com AHC foram produzidas pelo método de deslocamento do solvente modificado previamente referenciado na literatura ${ }^{[27]}$ Resumidamente, $10 \mathrm{mg}$ de AHC foram suspensos em $20 \mathrm{~mL}$ de metanol e, simultaneamente, $250 \mathrm{mg}$ de PCL foram dissolvidos $50 \mathrm{~mL}$ de acetona durante aproximadamente $30 \mathrm{~min}$. Estas preparações foram adicionadas sob agitação a $100 \mathrm{rpm}$ (IKA Labortechnik RW 20n, Alemanha) a $100 \mathrm{~mL}$ de fase aquosa externa que continha $2 \%(\mathrm{v} / \mathrm{v})$ de TWEEN 80 . As partículas formaram-se instantaneamente. Foram também produzidas NPs vazias.

\section{Método de recuperação das NPs}

A acetona foi removida num evaporador rotativo a $40 \mathrm{C}$ e as NPs obtidas foram depois recuperadas da fase aquosa por centrifugação (Centrífuga High Speed Table Top Z 36 HK, Hermle Labortechnik, Alemanha) a uma velocidade agitação de $37130 \mathrm{~g},-4 \mathrm{C}$ durante $40 \mathrm{~min}$. 


\section{Nps characterization}

Empty and HCA-loaded PCL NPs were characterized in terms of the mean particle size and zeta potential. These parameters were measured in triplicate and were determined by photon spectroscopy and electrophoretic mobility with the Coulter Nano-sizer (Delsa NanoTM C, Beckman Coulter, Inc., USA), respectively. Polydispersity index was also evaluated.

\section{Encapsulation efficiency (EE) of HCA into NPs}

The non-encapsulated HCA (or free-HCA) was recovered from HCA-loaded PCL NP by centrifugation (37197 $g$ during $40 \mathrm{~min}$ ). The EE was determined in triplicate by HPLC analysis of the freeHCA present in the supernatant using an optimization of a previously described HPLC method [28]. The HPLC system (Agilent 1100 series) includes a RP-18 column $(250 \times 4 \mathrm{~mm}$ internal diameter with a pore size of $5 \mu \mathrm{m})$. The experimental conditions were: an injection volume of $10 \mathrm{~L}$ and flow rate of $1.2 \mathrm{~mL} / \mathrm{min}$ at room temperature. The mobile phase was a mixture of deionized water, acetonitrile and methanol (58:32:10, $\mathrm{v} / \mathrm{v} / \mathrm{v}$ ) and elution was carried out in isocratic conditions with detection at $238 \mathrm{~nm}$. All standard solutions were dissolved in methanol. DM was used as internal standard. $\mathrm{HC}$ and $\mathrm{CA}$ were used in the optimization stages of method development to assure baseline resolution of DM, HCA and its two main degradation products. The method was validated for linearity in the range 5-100 ppm and accuracy and precision (intra- and interday) at two different levels of concentration, in agreement with international guidelines ${ }^{[29]}$.

\section{In vitro drug release assay}

HCA-loaded NPs $(10 \mathrm{mg})$ were placed in a recipient containing $20 \mathrm{~mL}$ of PBS (pH 7.4) (USP XXX) without enzymes and incubated at room temperature under constant stirring $(130 \mathrm{rpm})$. At appropriated time intervals, aliquots were collected and replaced immediately with fresh solution. A clear supernatant was obtained after an ultracentrifugation $(68600 \mathrm{~g}$ for $30 \mathrm{~min}$ ). HCA concentration in the supernatant was determined in triplicate using a UV-visible spectrophotometer (Evolution 600, UK). A standard calibration curve was performed with the HCA solution in PBS 7.4. The established range was 1-25 $\mu \mathrm{gmL}^{-1}\left(\mathrm{R}^{2}>0.999\right)$.

\section{Hydrophobic ointment preparation}

In short, white vaseline and white beeswax were placed together in a metallic capsule put previously in a water bath (J.P. Selecta, Spain) at 70C. The melted

\section{Caracterização das NPs}

As NPs de PCL vazias e carregadas com HCA foram caracterizadas em termos do tamanho médio de partícula e potencial zeta. Estes parâmetros foram medidos em triplicado por espectroscopia de fotão e mobilidade electroforética com o Coulter Nano-sizer (Delsa NanoTM C, Beckman Coulter, Inc., EUA), respectivamente. $\mathrm{O}$ índice de polidispersão foi também avaliado.

\section{Eficiência de encapsulação (EE) do AHC nas NPs}

A AHC livre ou não encapsulada foi isolada através de centrifugação (37197 $g$ duante $40 \mathrm{~min}$ ) e a EE foi determinada em triplicado através da quantificação do AHC livre, presente no sobrenadante por optimização de um método de HPLC previamente descrito [28]. O sistema HPLC (Agilent série 1100) incluiu uma coluna RP-18 (250x4mm diâmetro interno com $5 \mu \mathrm{m}$ de tamanho do poro). Utilizou-se um volume de injecção de $10 \mathrm{~L}$ e um fluxo de $1,2 \mathrm{mLmin}^{-1}$ com eluição à temperatura ambiente. A fase móvel era composta por uma mistura de água desionizada, acetonitrilo e metanol (58:32:10, v/v/v) e a eluição foi desenvolvida sob condições isocráticas. O comprimento de onda de deteção foi $238 \mathrm{~nm}$. Todas as soluções padrão foram dissolvidas em metanol. A DM foi utilizada como padrão interno. $\mathrm{O} \mathrm{HC}$ e a $\mathrm{AC}$ foram usados unicamente no desenvolvimento no método, para assegurar resolução na linha de base da $\mathrm{DM}$, do AHC livre e dos seus produtos de degradação. $\mathrm{O}$ método analítico foi validado para linearidade na gama 5 a 100 ppm e precisão e exactidão (intra- e interdia) a dois níveis de concentração, de acordo com directrizes internacionais [29].

\section{Ensaio de libertação in vitro}

As NPs carregadas com AHC (10 mg) foram colocadas num recipiente com $20 \mathrm{~mL}$ de PBS pH 7,4 (USP XXX) sem enzimas e incubadas à temperatura ambiente, sob agitação constante $(130 \mathrm{rpm})$. Em intervalos apropriados, foram colhidas alíquotas e substituídas imediatamente por tampão fresco. Obteve-se um sobrenadante límpido após ultracentrifugação (68600 $g$ durante $30 \mathrm{~min}$ ). A concentração de AHC no sobrenadante foi determinada em triplicado usando um espectrofotómetro UV-visível (Evolution 600, Reino Unido). Foi construída uma curva de calibração para a solução de AHC em PBS pH 7,4. Estabeleceu-se um intervalo de concentrações entre $1-25 \mu \mathrm{gmL}^{-1}\left(\mathrm{R}^{2}\right.$ $>0,999)$.

\section{Preparação da pomada hidrofóbica}

Resumidamente, a vaselina branca e a cera de abelha branca foram colocadas numa cápsula metálica colocada previamente num banho de água (J.P. Selecta, 
compounds were mixed and then the mixture was removed from a thermostatic bath with continuous stirring until a suitable consistency was obtained. Finally, the ointment was placed into a sterile flask.

\section{Incorporation of NPs into hydrophobic ointment} In summary, $1 \%$ (means $0.0256 \mathrm{~g} \mathrm{HCA}$ ) of empty PCL NPs $(0.1761 \mathrm{~g})$ (Figure 1$)$ was incorporated in $2.5 \mathrm{~g}$ of prepared white ointment (Figure 2) taking into consideration the EE value.

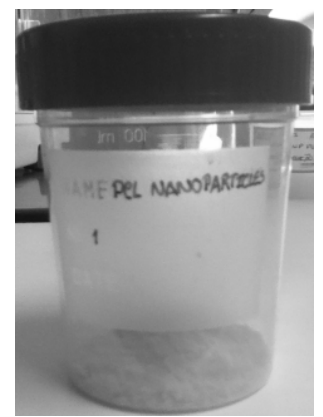

Figure 1 - Aspect of PCL Nps Figura 1 - Aspecto NPs de PCL

\section{Occlusive patch tests for safety evaluation of the NPs excipients}

Our previous in vitro results showed that these HCAloaded PCL NPs were not cytotoxic ${ }^{[27]}$. Thus, occluded patch tests were performed with 2 distinct formulations (white ointment and white ointment with incorporated empty PCL NPs) in an occlusive system and applied in 10 female human volunteers with different fototypes (II and III) during 48 hours. During this study, all human volunteers were questioned about their current medication and in all cases there was not reported use of anti-inflammatory or antihistaminic medicines. Informed written consent was obtained from all participants and the in vivo tests were performed in accordance with the approval of the local Ethical Committee. This dermatological test evaluated the occurrence of any possible skin reaction, such as allergic contact dermatitis, in accordance with international accepted literature ${ }^{[26]}$.
Espanha) a 70C. Os compostos fundidos foram misturados e, de seguida, a mistura foi removida do banho termostático com agitação contínua até se obter uma consistência adequada. Finalmente, a pomada obtida foi colocada num frasco estéril.

\section{Incorporação das NPs em pomada hidrófoba}

Sumariamente, $1 \%$ (correspondente a $0,0256 \mathrm{~g} \mathrm{AHC}$ ) das NPs de PCL vazias (0.1761 g) (Figura 1) foram incorporadas em $2.5 \mathrm{~g}$ pomada branca (Figura 2) preparada tendo em consideração a sua EE.

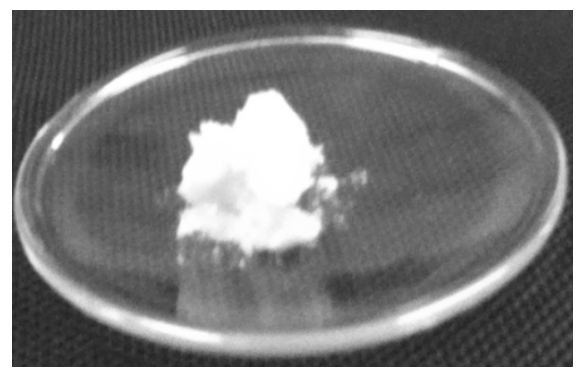

Figure 2 - Empty PCL NPs in an oinment

Figura 2-NPs de PCL vazias incorporadas numa pomada.

\section{Testes oclusivos para avaliação da segurança dos excipientes das NPs}

Os nossos anteriores resultados in vitro demonstraram que as NPs de PCL carregadas com AHC não foram citotóxicas ${ }^{[29]}$. Por conseguinte, foram desenvolvidos testes oclusivos com 2 formulações distintas (pomada branca e pomada branca com NPs de PCL vazias) e aplicadas em 10 voluntários humanos do sexo feminino com diferentes fotótipos (II e III) durante 48 horas. Durante este estudo, todos os voluntários humanos foram questionados acerca da sua presente medicação e, em todos os casos, não foram relatados quaisquer usos de medicamentos anti-inflamatórios e anti-histamínicos. Para a realização dos testes in vivo, todos os voluntários assinaram um consentimento informado por escrito. Além disso, os ensaios foram realizados com aprovação do Comité Ético local. Estes testes dermatológicos avaliaram a ocorrência de eventuais reacções na pele, tal como dermatite de contacto alérgica, de acordo com a literatura internacionalmente reconhecida ${ }^{[26]}$. 


\section{Statistical analysis}

All data were statistically treated by $t$-student test and one-way ANOVA analysis (GraphPad Prism version 6.0a Software). Differences were considered statistically significant when $\mathrm{p} \leqslant 0.05$ and the confidence level used was $95 \%$.

\section{Results and discussion}

\section{NPs characterization}

HCA-loaded PCL NPs mean size was $258.424 .5 \mathrm{~nm}$ and lies within the size range considered adequate to penetrate the stratum corneum ${ }^{[30]}$. The encapsulation of HCA significantly increased the particle size as seen in Figure 3. The polydispersity index was 0.084 . This value indicates that the resultant NPs are very homogenous in terms of size ${ }^{[31]}$. In addition, regarding the nanosystems' stability, Fourier transform infrared (FTIR) spectroscopy conducted in our previous work [27] demonstrated that drug and NPs interacted by hydrogen bonding after encapsulation, with small spectrum variations over one week and reorientation to their original structures, as the drug was released from the NPs. On the other hand, zeta potential of NPs was $4.390 .62 \mathrm{mV}$ (Figure 4). The encapsulation of HCA also significantly changed the zeta potential of the NPs. This negative charge of NPs may be crucial in the interaction with the positive charge of the human skin $(+23 \mathrm{mV}){ }^{[32]}$ and, thus, increases the time the NPs formulation remains in the target tissue. However, some studies suggest that nanosystems with positive surface charge also interact with skin lipidic constituents and hair follicles negatively charged; therefore, NPs penetration are promoted until they reach deep skin layers such as the dermis ${ }^{[33,34]}$. Consequently, further studies should focus on NPs penetration through the skin and measure their skin depth penetration.

\section{Análise estatística}

Os dados foram tratados estatisticamente por análise e teste $t$-student e one-way ANOVA (software GraphPad Prism versão 6.0a). Foram consideradas diferenças significativas quando $p \leqslant 0,05$ com um limite de confiança de $95 \%$.

\section{Resultados e discussão}

\section{Caracterização das NPs}

O tamanho médio das NPs com AHC foi 258,4 24,5 $\mathrm{nm}$ e encontra-se dentro da gama de tamanhos considerados suficientes e adequados para penetrar o estrato córneo ${ }^{[30]}$. A encapsulação do AHC conduziu a um aumento significativo do tamanho das NPs conforme demonstra a Figura 3. O índice de polidispersão foi de 0,084 . Este valor indica que as NPs produzidas são muito homogéneas em termos de tamanho ${ }^{[31]}$. Além disso, em termos da estabilidade dos nanosistemas, a espectroscopia no infravermelho por transformada de Fourier (FTIV) conduzida no nosso estudo anterior ${ }^{[27]}$, demonstrou que, após encapsulação, o fármaco e as NPs interagiram através de pontes de hidrogénio, com pequenas variações do espectro ao longo de uma semana e com reorientação para as suas estruturas originais, à medida que o fármaco era libertado das NPs. Por outro lado, o potencial zeta das NPs foi de $-4.390 .62 \mathrm{mV}$ para as NPs (Figura 4). A encapsulação do AHC também influenciou significativamente o potencial zeta das NPs. Esta carga negativa das NPs poderá ser crucial para a interacção com pele humana, que geralmente apresenta uma carga geral positiva $(+23 \mathrm{mV})$ e tal facto poderá aumentar o tempo de residência da formulação de NPs no tecido alvo ${ }^{[32]}$. Contudo, alguns estudos sugerem também que nanosistemas com carga superficial positiva interagem com os constituintes lipídicos da pele e os folículos pilosos carregados negativamente. Por esse motivo, a penetração de NPs é promovida até estas chegarem às camadas profundas da pele, tais como a derme ${ }^{[33,34]}$. Consequentemente, estudos futuros deverão avaliar a penetração das NPs de PCL na espessura total de uma amostra de pele e medir a sua profundidade de penetração através das camadas da pele. 


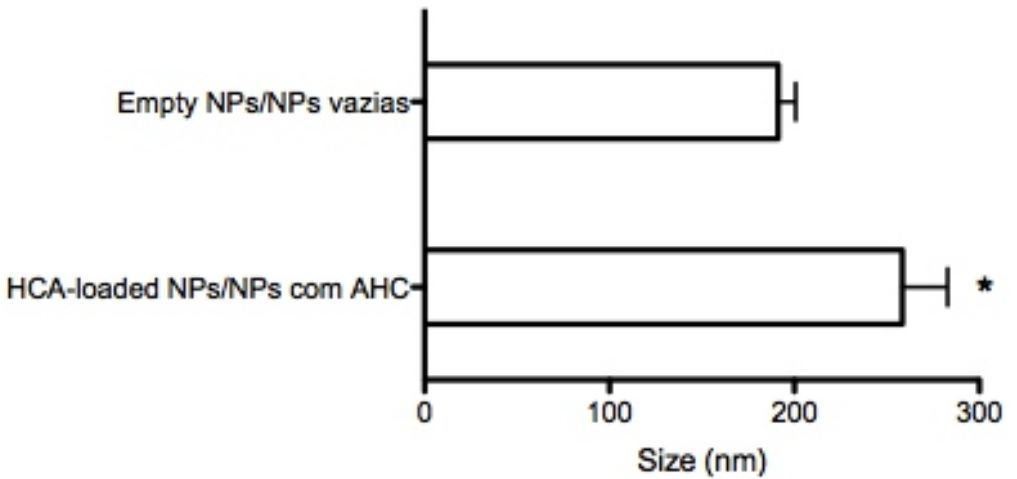

Figure 3 - Mean particle size of empty and HCA-loaded PCL NPs ( $\mathrm{n}=3$ ).

Figura 3 -Tamanho médio das NPs de PCL vazias e carregadas com $\mathrm{AHC}(\mathrm{n}=3)$.

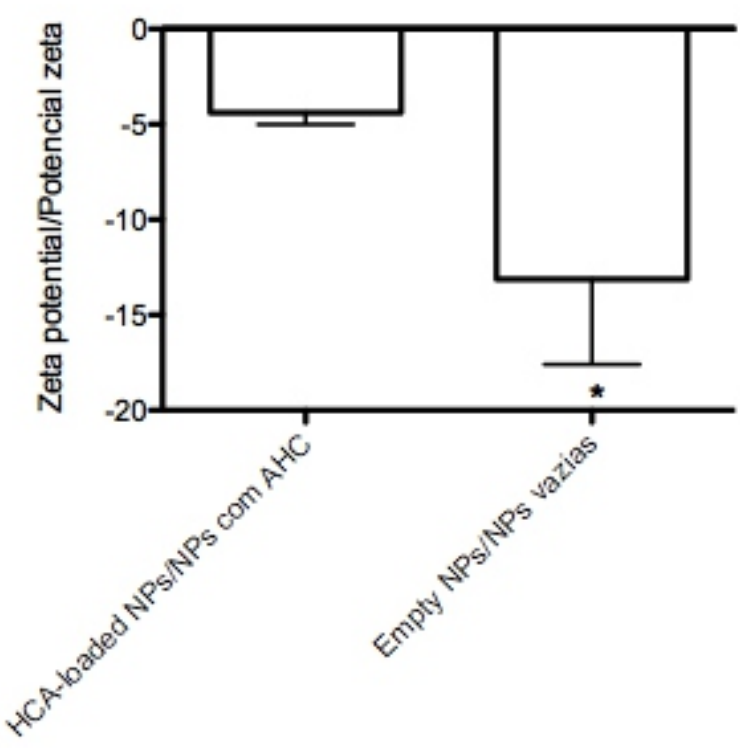

\section{EE of HCA into NPs}

HPLC parameters are outlined in Tables 1 and 2. The HPLC method was linear with $\mathrm{R}^{2} 0.9995$ within the concentration range. The average retention time \pm SD for HCA and DM were $10.41 \pm 0.16 \mathrm{~min}$ and $6.91 \pm$ $0.09 \mathrm{~min}$, respectively. The peaks were fully resolved at the baseline. The EE was $36.320 .03 \%$. A higher value of EE was expected since both PCL and HCA present lipophilic characters and PCL has generally demonstrated higher values for EE of lipophilic drugs ${ }^{[35]}$. However, similarly to previous studies, our value of EE could be due to the high solubility of PCL in the organic phase which was later removed ${ }^{[36]}$.
Figure 4 - Mean zeta potential of empty and HCA-loaded PCL $\operatorname{NPs}(n=3)$.

/Figura 4 - Potencial zeta médio das NPs de PCL vazias e carregadas com $\mathrm{AHC}(\mathrm{n}=3)$.

\section{EE do AHC nas NPs}

Os parâmetros de HPLC estão descritos nas Tabelas $1 \mathrm{e}$ 2. O método de HPLC revelou-se linear na gama das concentrações estudadas com $\mathrm{R}^{2}$ 0,9995. O tempo médio de retenção da $\mathrm{ACH}$ e da DM foi de $10 ., 41 \pm 0,16$ min e 6,91 $\pm 0,09 \mathrm{~min}$, respectivamente. Os picos apresentam boa resolução. Neste estudo, a EE foi 36,32 $0,03 \%$. De acordo com os resultados, era expectável obter um valor superior, uma vez que tanto a PCL como o AHC apresentam um carácter lipofílico como previamente descrito ${ }^{[35]}$. Contudo, o valor obtido da EE poderá estar relacionado com a elevada solubilidade da PCL na fase orgânica que foi posteriormente eliminada, tal como observado em outros estudos anteriores $^{[36]}$. 
Table 1 - Linear regression parameters related to HCA standard solutions used in HPLC analysis

Tabela 1 - Parâmetros da Regressão linear relacionadas com as soluções padrão de HCA usadas na análise em HPLC.

\begin{tabular}{|l|l|}
\hline $\begin{array}{l}\mathbf{m} \text { (Slope) } \\
m \text { (Declive) }\end{array}$ & $0,1128 \pm 0,0009$ \\
\hline $\begin{array}{l}\mathbf{y} \text { (HCA Area/DM Area) } \\
y \text { (AHC Área/DM Área) }\end{array}$ & $-0,061 \pm 0,049$ \\
\hline $\begin{array}{l}\mathbf{x} \text { (HCA Concentration) } \\
x \text { (AHC Concentração) }\end{array}$ & 0,541 \\
\hline $\begin{array}{l}\mathbf{R} \text { (Correlation coefficient) } \\
R \text { (Coeficiente de Correlação }\end{array}$ & 0,9995 \\
\hline
\end{tabular}

\section{In vitro release studies}

PCL NPs showed a prolonged drug release as demonstrated in Figure 5. It was observed that only $7 \%$ of the drug was released from the NPs after $24 \mathrm{~h}$. This low cumulative amount of released HCA can be explained by the fact that hydrophobic polymer PCL can retain hydrophobic drugs such as HCA.
Table 2 - Retention times of HCA and DM. Tabela 2 -Tempos de retenção do AHC e DM.

\begin{tabular}{|l|l|}
\hline $\begin{array}{l}\text { Retention time of HCA } \\
\text { Tempo de Retenção do AHC }\end{array}$ & $10.41 \pm 0.16 \mathrm{~min}$ \\
\hline $\begin{array}{l}\text { Retention time of DM/ } \\
\text { Tempo de Retenção da DM }\end{array}$ & $6.91 \pm 0.09 \mathrm{~min}$ \\
\hline
\end{tabular}

\section{Estudos de libertação in vitro}

As NPs de PCL conduziram a um perfil de libertação prolongado do AHC como demonstrado na Figura 5. Foi observado que apenas $7 \%$ do fármaco foi libertado a partir das NPs após $24 \mathrm{~h}$. A quantidade de AHC libertado é de facto muito baixa e pode estar relacionada com a capacidade de retenção de fármacos hidrofóbicos, tais como o AHC, por parte do polímero usado.

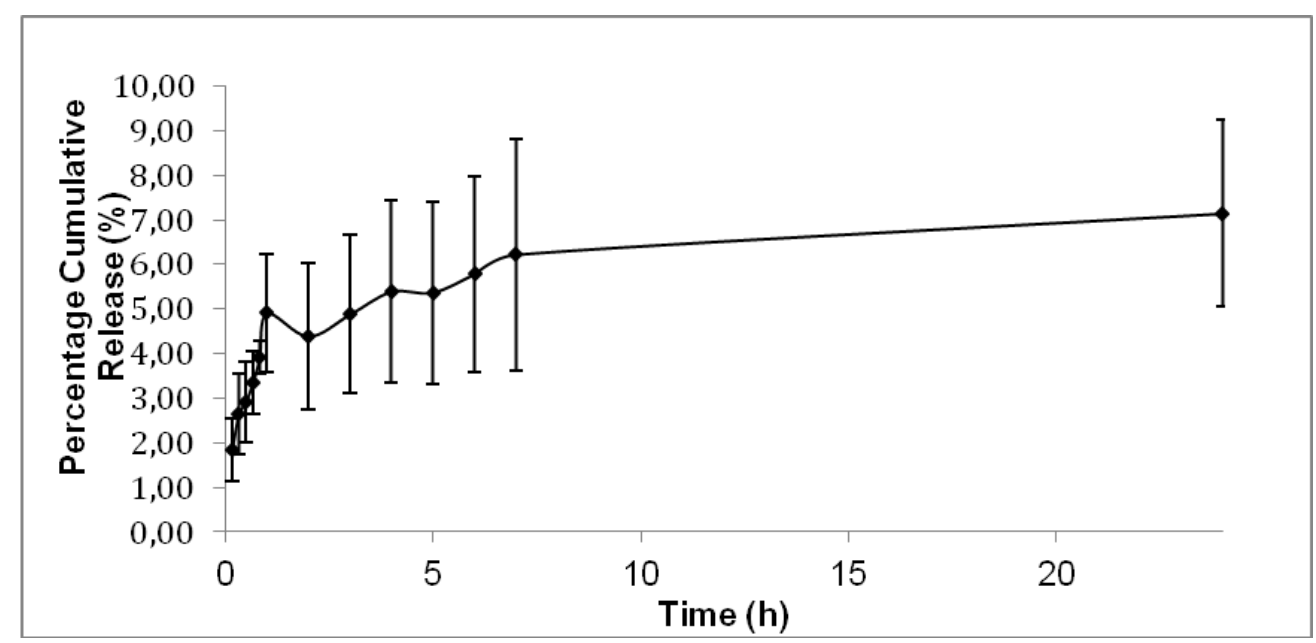

Figure 5 - In vitro cumulative release of HCA from PCL NPs in PBS buffer ( $\mathrm{pH} 7.4)($ Mean $\pm \mathrm{SD}, \mathrm{n}=3$ )

Figura 5 - Perfil de libertação in vitro do AHC das NPs de PCL em tampão PBS (pH 7,4) (Média \pm SD, n=3) 


\section{Occluded patch test for safety evaluation of NPs excipients}

The assessment of excipients safety of empty PCL NPs demonstrated total absence of adverse side effects in all human volunteers, as seen in Figure 6.

\section{Testes oclusivos para avaliação da segurança de excipientes das NPs}

A avaliação da segurança dos excipientes de NPs de PCL sem fármaco demonstrou total ausência de reações secundárias em todos os voluntários humanos, como demonstrada a Figura 6.

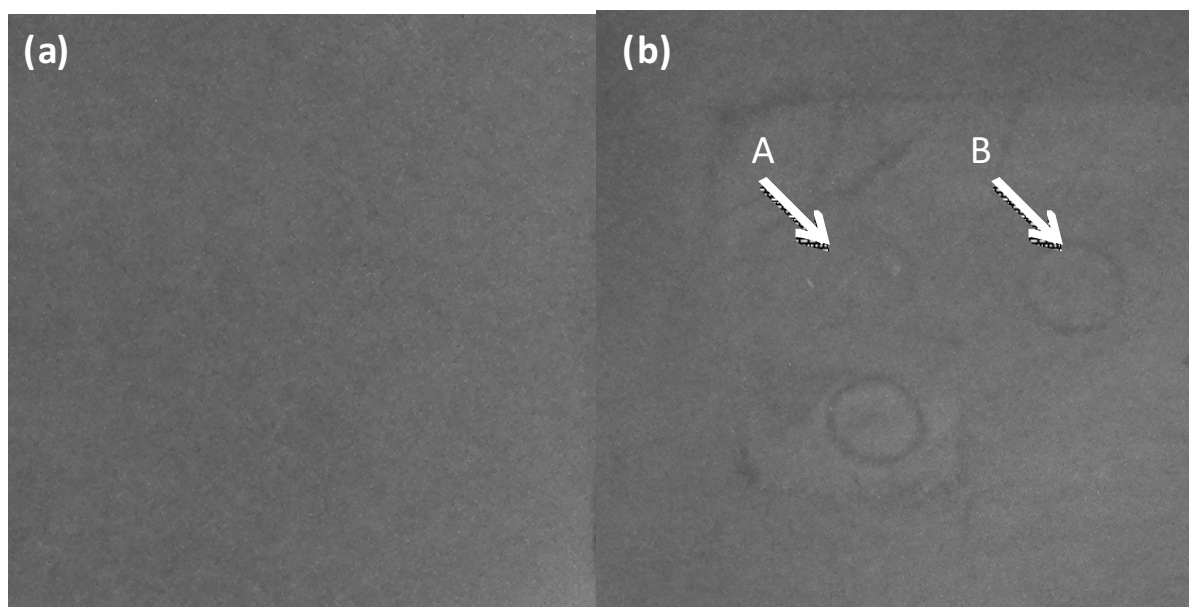

Figure 6 - Human skin appearance: (a) Before and (b) After occluded patch test: A - Empty PCL NPs formulation and B - Hydrophobic ointment.

Figura 6 - Aparência da pele humana: (a) Antes e (b) Após os testes oclusivos: A Formulação de NPs de PCL vazias e B - Pomada hidrofóbica.

\section{Conclusions}

We successfully prepared and characterized the HCAloaded PCL NPs since these NPs were demonstrated to be a potential drug delivery system with uniform particle size that increases the probability of skin penetration. The negative surface charge may also be an effective way of achieving a prolonged drug release due to established electrostatic interactions between the NPs and the human skin. In addition, HCA was released from NPs in a prolonged manner. Concerning safety, blank NPs did not show adverse effects. However, further studies should be performed in order to optimize EE.

\section{Conflict of Interests}

The authors declare that there are no financial and personal relationships that could be viewed as presenting a potential conflict of interests.

\section{Conclusões}

Os objectivos deste estudo foram alcançados uma vez que estas NPs demonstraram ser um sistema de veiculação de fármaco adequado com um tamanho de partículas uniforme e que aumenta a probabilidade de penetração na pele. A carga de superfície negativa poderá ainda conferir uma forma eficaz de alcançar uma libertação de fármaco prolongada devido às interacções electrostáticas estabelecidas entra as NPs e a pele humana. O AHC foi ainda libertado das NPs de uma forma prolongada. Em termos de segurança, as NPs não conduziram a nenhum efeito adverso. Porém, estudos futuros deverão ser desenvolvidos de forma a optimizar a EE.

\section{Conflito de Interesses}

Os autores declaram que não há relações pessoais e financeiros que poderiam ser vistas como apresentando um potencial conflito de interesses. 


\section{References / Referências}

[1]. Cork MJ, Danby SG, Vasilopoulos Y, Hadgraft J, Lane ME, Moustafa M, Guy RH, MacGowan AL, Tazi-Ahnini R, Ward SJ. Epidermal barrier dysfunction in atopic dermatitis. Journal of Investigative Dermatology 2009; 129(8):18921908. [2]. De Benedetto A, Agnihothri R, McGirt LY, Bankova LG, Beck LA. Atopic dermatitis: A disease caused by innate immune defects? Journal of Investigative Dermatology 2009; 129(1): 1430 .

[3]. Elias PM, Schmuth M. Abnormal skin barrier in the etiopathogenesis of atopic dermatitis. Current Opinion in Allergy and Clinical Immunology 2009; 9(5):437446.

[4]Furue M, Takeuchi S. Topical tacrolimus as treatment of atopic dermatitis. Clinical, Cosmetic and Investigational Dermatology 2009; 2:161166. [5]. Hamid Q, Boguniewicz M, Leung DYM. Differential in situ cytokine gene expression in acute versus chronic atopic dermatitis. The Journal of Clinical Investigation 1994; 94(2):870876.

[6]. Irvine $\mathrm{AD}$, McLean WHI. Breaking the (un)sound barrier: Filaggrin is a major gene for atopic dermatitis. Journal of Investigative Dermatology 2006; 126(6):12001202.

[7]. Jin H, He R, Oyoshi M, Geha RS. Animal models of atopic dermatitis. Journal of Investigative Dermatology 2009; 129:3140.

[8]. Krakowski AC, Eichenfield LF, Dohil MA. Management of atopic dermatitis in the pediatric 2008; 122(4):812-824.

[9]. Darsow U, Lübbe J, Taïeb A, Seidenari S, Wollenberg A, Calza AM, Giusti F, Ring J. Position paper on diagnosis and treatment of atopic dermatitis. Journal of the European Academy of Dermatology and Venereology 2005; 19(3):286295. [10]. Leung DYM, Boguniewicz M, Howell MD, Nomura I, Hamid QA. New insights into atopic dermatitis. The Journal of Clinical Investigation 2004; 113(5):651657.

[11]. Rehal B, Armstrong AW. Health outcome measures in atopic dermatitis: A systematic review of trends in disease severity and quality-of-life instruments 1985-2010. PLoS ONE 2011; 6(4):e17520

[12]. Williams HC. Atopic Dermatitis. The New England Journal of Medicine 2005; 352:23142324. [13]. Elias PM. Therapeutic implications of a barrierbased pathogenesis of atopic dermatitis. Annals of Dermatology 2010;22(3):245254.
[14]. Imokawa G, Abe A, Jin K, Higaki Y, Kawashima M, Hidano A. Decreased level of ceramides in stratum corneum of atopic dermatitis: An etiologic factor in atopic dry skin?. Journal of Investigative Dermatology 1991; 96:523-526

[15]. Komine M. Analysis of the mechanism for the development of allergic skin inflammation and the application for its treatment: Keratinocytes in atopic dermatitis Their pathogenic involvement. Journal of Pharmacological Sciences 2009; 110(3):260-264. [16]. Taro Pharmaceuticals U.S.A., Inc.. U-CORT Hydrocortisone acetate cream. 2008 Dec. in: URL: h t t p : / $\quad$ n c c s - d a i l y m e d 1.nlm.nih.gov/dailymed/archives/fdaDrugInfo.cfm? archiveid=10249Choi JJ, Park B, Kim DH, Pyo MY [17]. Choi S, Son M, Jin M. Blockade of atopic dermatitis-like skin lesions by DA-9102, a natura medicine isolated from Actinidis arguta, in the $\mathrm{Mg}$ deficiency induced dermatitis model of hairless rats. Experimental Biology and Medicine 2008; 233:10261034.

[18]. De Jong WH, Borm PJ. Drug delivery and nanoparticles: Applications and hazards International Journal of Nanomedicine 2008 3(2):133149.

[19]. Park K. Nanotechnology: What it can do for drug delivery. Journal of Controlled Release. 2007 120(1-2): 13 .

[20]. Ochekpe NA, Olorunfemi PO, Ngwuluka NC. Nanotechnology and Drug Delivery Part 1: Background and Applications. Tropical Journal of Pharmaceutical Research.2009; 8(3):265274.

[21]. Medina C, Santos-Martinez MJ, Radomski A Corrigan OI, Radomski MW. Nanoparticles Pharmacological and toxicological significance. British Journal of Pharmacology 2007 150(5):552558.

[22]. Soppimath KS, Aminabhavi TM, Kulkarni AR Rudzinski WE. Biodegradable polymeric nanoparticles as drug delivery devices. Journal of Controlled Release 2001; 70(1-2): 120.

[23]. Ulbrich W, Lamprecht A. Targeted drug-delivery approaches by nanoparticulate carriers in the therapy of inflammatory diseases. Joumal of the Royal Society Interface 2010; 7(1):S55S66.

[24]. Mei L, Sun H, Song C. Local delivery of modified paclitaxel-loaded poly(-caprolactone)/pluronic F68 nanoparticles for long-term inhibition of hyperplasia. Journa of Pharmaceutical Sciences 2009; 98(6):20402050.
[25]. Sinha VR, Bansal K, Kaushik R, Kumria R, Trehan A. Poly--caprolactone microspheres and nanospheres: An overview. International Journal of Pharmaceutics 2004; 278(1): 123 .

[26]. Chawla JS, Amiji MM. Biodegradable poly(epsilon -caprolactone) nanoparticles for tumortargeted delivery of tamoxifen. International Journa of Pharmaceutics 2002; 249(1-2):127138.

[27]. Rosado C, Silva C, Reis C. Hydrocortisoneloaded poly( $\mathcal{E}$-caprolactone) nanoparticles for atopic dermatitis treatment. Pharmaceutical Development and Technology 2013; 18(3):710718.

[28]. Hájková R, Solich P, Dvorák J, Sícha J. Simultaneous determination of methylparaben, propylparaben, hydrocortisone acetate and its degradation products in a topical cream by RPHPLC. Jounal of Pharmaceutical and Biomedical Analysis 2003; 32(4-5):921927.

[29]. Group IEW. ICH Harmonised Tripartite Guideline - Validation of Analytical Procedures: Text and Methodology Q2(R1). 2005.

[30]. Reis ACBP. Encapsulação de Fármacos P e p tíd i cos pelo Mét od o d e Emulsificação/Gelificação Interna; 2007

[31]. Choi, M., Maibach, H., Liposomes and niosomes as topical drug delivery systems. Skin Pharmacol Physiol. 2005; 18(5): 209-219.

[32]. Morykwas MJ, Thornton JW, Bartlett RH. Zeta potential of synthetic and biological skin substitutes: Effects on initial adherence. Plastic \& Reconstructive Surgery 1987; 79(5):732739

[33]. Jung S, Otberg N, Thiede G, Richter H, Sterry W, Panzner S, Ladermann J. Innovative liposomes as a transfollicular drug delivery system: Penetration into porcine hair follicles. Journal of Investigative Dermatology 2006; 126:17281732.

[34[. Desai P, Patlolla RR, Singh M. Interaction of nanoparticles and cell-penetrating peptides with skin for transdermal drug delivery. Molecular Membrane Biology 2010; 27(7):247259.

[35]. Pérez MH, Zinutti C, Lamprecht A, Ulbrich N, Astier A, Hoffman M, et al. The preparation and evaluation of poly(eplsilon-caprolactone) microparticles containing both a lipophilic and a hydrophilic drug. Journal of Controlled Release 2000; 65(3):429438.

[36]. Yeo Y, Park K. Control of encapsulation efficiency and Initial burst in polymeric microparticle systems. Archives of Pharmacal Research 2004; 27(1):112. 